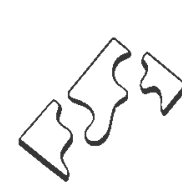

\title{
The Theory-Practice Relation in Critical \\ Pedagogy
}

Siebren Miedema

Leiden University

The Netherlands

If we consider empirical-analytical, hermeneutical, and critical pedagogy from the viewpoint of the relation between theory and practice, the opinions of Greek philosophy seem to repeat themselves. Preeminent to the hermeneutical, Socratic version, is the practice of child raising and education. Here the function of theory is to clarify the practice situations and to make the practitioners aware of what is going on in the pedagogical relations and situations in which they are involved. So, we could say practice looks in the mirror of theory. Sometimes it looks as if theory could play a pioneering role in the realization of practice. However, the direction in which theory can and should influence and possibly modify practice remains unclear, because theory has made itself all too dependent on the existing practice, which is largely determined by tradition. This is, for instance, very clear in the work of the hermeneutical pedagogue Erich Weniger (1975). In all his didactic work the scientific theory is the follower of the practical theories of the practitioners and never takes a leading position with regard to future situations and relations. Apart from this, there is no explicit (critical) social theory and analysis that could guide future action. This does not, however, mean that there are no opinions on society or of the roles that social forces and institutions play. Aristotle had separated and relatively isolated theory from practice. Scientific theory is developed on the basis of a mere theoretical interest in the truth of propositions about facts and cannot be related in a direct way to human practice. Empirical-analytical or behavioral pedagogy has radicalized Aristotle's separation of theory and practice. Here theory has an absolute priority and practice is its field of application. The bridge is theory-technology-application.

A Platonic version of critical pedagogy gives priority to theory too. Individual and collective action must be influenced or changed on the basis of the theoretical ideas about what is Good and True. The critical and prescriptive content of theory must be based on social analysis. But where theory ignores the relatively autonomous status and nature of practice it does so to its own detriment. After all, practice is no tabula rasa nor just a theoretically constructed straight-on practice (orthopraxis); in pedagogical action itself norms and practice theories play quite a substantial role. 


\section{Emancipation and Child Raising}

The core concept of critical pedagogy is emancipation: Every human being and hence every child must be given the possibility by way of analysis, criticism, and self-reflection to develop into a freely selfdetermining and rationally acting person. These possibilities for self-determination must not be limited by material power, ideologies, or prejudice. The concept of emancipation provides an anthropological model that is both dynamic and formal. Strikingly, even at its core concept of emancipation, critical pedagogy remains formally theoretical. In that respect it closely resembles the critical theory of Habermas who inspired it. Habermas $(1970,1971,1984)$, with his theory of knowledge-leading interests, complemented later with the concepts of communicative competence, offers a justification for, but not a theory of, emancipation. Habermas has given a legitimation on a theoretical level for the emancipation of, for example, black persons and women, but did not tell us or them what should be done in reaching that emancipation.

One of the consequences is that child raising, when described as emancipation, also results in a formal concept of child raising. Several definitions of emancipation have been given. Mollenhauer (1977), for instance, called emancipation in child raising the process by which young people are liberated from the conditions which restrict their autonomy and competence in self-reflection. In 222 Lempert's (1969) view emancipation is the process of setting people free from the compulsion of material power, as well as from ideologies and prejudices, with the help of analysis, critique, and self-reflection. For Klafki $(1970$, p. 26; 1982, pp. 19, 20), at the individual level, child raising is aimed at self-reliance, self-responsibility, and self- and codetermination. Socially it is directed at sociability and solidarity.

The formal nature of the critical concept of child raising disappointed many pedagogues and they turned away from critical pedagogy. In the Netherlands, for example, acceptance of critical pedagogy has been minimal. It was primarily at the level of theoretical pedagogy that attention was paid to the ideas of Habermas and his followers in education. What has been decisive here is, of course, the preeminently hermeneutically impregnated character of Dutch pedagogy. To a large extent this is due to the enormous influence of Langeveld (cf. Miedema, 1984b). In addition, there were the limitations of critical pedagogy itself when it came to material possibilities. The German critical pedagogues expressed their own doubts. For instance, not without irony, critical pedagogy has been called a "philosophy of science without science" and without a concrete subject. It has been criticized as a pedagogy that stresses theory, that is merely capable of criticism, of producing a formal concept of child raising but without being able to offer directions for action. 
Although this judgment comprises some elements of truth in regard to the aspect of the philosophy of science, it need not by any means be the final assessment of the critical-pedagogical concept of child raising. One of the arguments for this claim is that the concept of child raising in critical pedagogy does not allow for any prior material filling-in because, according to critical pedagogues, the material content of the concept must be determined separately for every historical-social situation. The economic, social, and political aspects of a context have to be taken into account and only on that basis can there be an adequate filling-in. And it is within the bounds of possibilities to do this.

\section{Klafki's Proposals}

If critical pedagogy is also incapable of offering beforehand practical directions for action, then does this version of the relationship between theory and practice also leave the practitioners to their own resorts?

Klafki (1970) in trying to avoid this pitfall, formulated four theses on the relation between theory and practice within critical pedagogy. In accordance with the tradition of hermeneutical pedagogy in Germany, critical pedagogy had to make the implicit part of the pedagogical practice explicit for the practitioners (the first thesis). But still more had to be done. The pedagogical practice had to be placed within its own historical process. "Pedagogy can give pedagogical practitioners a consciousness of their historical situation, the historical presuppositions of their work, a historically founded consciousness of the present" (p. 25). The function of pedagogy for both practice and historical enlightenment can be either conservative or critical. In the first case teachers, school organizers, and politicians are seen to be engaged in conserving traditions. Critical pedagogy, however, wants to preserve the usable aspects of tradition at the same time as it criticizes elements of self-deception, false consciousness, and ideology where these are present in pedagogical practice (the second thesis). Such a critique can be formed by research into the economic, social, and political presuppositions, limits, dependences, and implications of a pedagogical process. But the knife of the critique cuts two ways. Pedagogical theory must also be prepared to direct the processes of enlightenment and critique at itself.

Why was pedagogical theory, at least until a short while ago, so blind to the economic, social, and political dimensions of education? (the third thesis). According to Klafki, pedagogical research and theory on the one hand and pedagogical practice on the other are dependent on each other; there is a permanent feedback process. What is needed is cooperation between pedagogical theorists and practitioners (the fourth thesis). And in his later work, starting in 1971, we find that for Klafki, action research is one of the most promising 
means of realizing such a cooperation. In order to prevent one-way traffic from critical theory to practice, and thus to mediate between theory and practice, a close contact is needed between critical pedagogues and practitioners, parents, and children. If critical pedagogy is to be seen as a theory of child raising with a direct, concrete relation to its flesh and blood subjects, then a process of cooperation is necessary between all those people involved, to the equal benefit of children, parents, and pedagogical practitioners.

\section{Action Research as Critical Method Par Excellence}

To realize these ends the research method action research as described by Lewin (1958) has been revived by critical pedagogues. They see critical action research as the method par excellence for developing cooperation between all parties involved: between scientists, professional practitioners (such as teachers, helpers), parents, and children. In this way concrete persons once again find a place in critical pedagogy. It is a movement toward daily action, toward the world in which all those parties involved live.

In West Germany and the Netherlands action research at first manifested itself primarily as a methodology of controversy. In particular, it criticized the scientific, strongly reductive way in which empirical-analytical pedagogues carried out research. Traditional empirical-analytical research is science-oriented and productoriented research with an implementation strategy in which knowledge is available to practice only after the total research is done. In contrast, critical action researchers decided in favor of a practice and process orientation, and a direct feedback of acquired knowledge. Action research is a strategy intended to make cooperation possible with an involved and influential role for researchers close to practice and together with all practitioners. This should lead to a joint determination of problem choice and problem definitions by all participants and a hermeneutical ideological renewal of practice instead of a technological renewal. In critical action research it is of minor importance who formulates the question or takes the initiative. The only touchstone is the joint problem determination as a consensus of all participants. In critical action research the element of practice is relatively autonomous in relation to scientific theory and can never be a mere field of application of this theory. In action research, researchers make a political decision in taking the side of people and groups whose rights to self- and social interpretation have not been exploited. Epistemologically speaking, the knowledge of the researchers and the common sense knowledge of the other participants must be linked (Miedema, 1984a) with the risk of translation difficulties and breakdown in communications.

Although at present there is in the Netherlands and West Germany a growing tendency to orient oneself within the wider field of qualitative research and qualitative methods, action research has been 
one of the core issues in the positivist dispute in pedagogy during the 60 s and 70s. Action research can also be seen as the test case for critical pedagogical ideas about the relation between theory and practice.

\section{The Marburg Elementary School Project}

What can we say about action research in practice? Reports on research projects show that the core of this methodological variant of the theory-practice relationship, that is, cooperation between practitioners and researchers, often runs into serious problems. Communication problems frequently cause the discontinuation of projects.

Reports of critical action research projects that have been completed are rather rare. One such project is the Marburg Elementary School Project (Klafki, 1975; Klafki et al., 1982) carried out under the direction of Wolfgang Klafki. Over the past 15 years Klafki has expressed his views on methodology and on the philosophy of science in numerous publications. Action research has also received his unrestricted attention. This obviously calls for a comparison between his programmatical opinions on critical pedagogy and the reality of action research. On the basis of reconstruction-research or meta-analysis carried out (Miedema, 1985), a more concrete form may be given to the question of the possibilities and problems of critical action research from the perspective of the theory-practice relation.

The Marburg Elementary School Project aimed to contribute to the elimination of unequal opportunities for children by developing didactic products and instruments to observe specific processes in education. The aim was to be realized by cooperation between researchers and teachers at five elementary schools. Children should be able to deal with the world of nature and with their social environment in a critical-productive way. In addition, they ought to be capable, in a relatively autonomous way, of self-determination, selfcontrol in learning processes, and conscious social learning. Renewal strategies were to be developed in the form of didactic measures, and free learning processes were to be stimulated to be able to realize the self- and codetermination of the children. A consensus was required among the researchers and teachers on strategies and measures to be chosen. During the project the researchers were to describe the processes of change in the classrooms (didactics and implementation of material) as accurately as possible. The process description and analysis were two of their specific tasks. Based on this the teachers were to be enabled to carry out their innovatory activities more successfully.

Contrary to the initial aims, however, the project process developed along other lines due to pressure from, among others, the teachers and a scientific advisory board (set up by the sponsor and including some die-hard empirical-analytical researchers). Instead of 
engaging in process analysis that was at first considered so important, during the main stage of the project almost all the attention was aimed at constructing curriculum units because the teachers preferred an aim-oriented approach that would produce practical and usable results for them. These curriculum units were to be products, didactic foundations, that had to be transferable to other situations, that is, to be generalizable to a limited extent. Other teachers would be able to use them independently, that is, without any help of researchers, and would also be able (on the basis of the process description and the analysis of the circumstantial conditions) to make changes in these units in order to make them fit their own eductional settings.

The teachers had asked for both curriculum units and observations of their classes. They wanted information about their own actions in relation to the conditions of the teaching and learning situations. Education students did the lion's share of the qualitative observations, but their activities had not been well prepared and could not be fully integrated in the whole project. By interviewing the teachers it was clear that these observations had hardly played any role in the planning and execution of the teaching processes. It was, therefore, doubtful which conditions and influences had played a part in bringing about the didactic-pedagogical changes in the project classes.

Within the project, when product orientation had the upper hand, written evaluations of products were carried out by teachers who were not directly involved in making the products. Many said they would expect to need support when actually using them; of course this was precisely not intended. The goals were greater competence and independence with regard to the innovative realization of aims. For the teachers it proved to be too great a task to find out whether the circumstances in class were comparable to the circumstances in which the products originated or that they should have been able to modify the unit. Only a more elaborated process approach, together with a product orientation, could make a limited generalizability of curriculum units possible for independent teachers. Teachers could then determine for themselves whether the circumstances in class were comparable to the circumstances in which the products originated and which had been described in the curriculum units, or whether the units should be modified in view of different peripheral conditions.

One of the striking effects of the change from a process orientation to a product orientation was the fixing of the different roles for teachers and researchers. The old contradiction seems to repeat itself here. The researchers became more and more involved with the theoretical planning of a curriculum unit and failed to give attention to the daily and practical problems of the teachers who were focused on the concrete teaching and learning situations. This task-fixation 
was caused in the first place by the pressure of time, which had an influence on the whole project process, and secondly by the expectation of the teachers that the researchers should be able to produce curriculum units usable for their own practical activities. ${ }^{1}$

In drawing some conclusions, we can say that the curriculum units produced, contrary to the initial aim, are not usable by other teachers independently. The teachers need some help, for example, through postgraduate or in-service training. Thus the products of this action research hover between science and practice. It did not, then, bridge the gap between theory and practice. Apart from this, the critical action research plainly gave priority to the innovatory aspects rather than to the research aspects. (The former even dominates.) By research aspects we mean, among other things, description and analysis of the process as tasks preeminently suited for scientists. After all, they do have more know-how when it comes to method techniques. Pressure of time and demands of the teachers led to a situation in this action research project where the researchers/scientists could no longer carry out their own relatively autonomous tasks: theory development and the application of research methods adequate to the object. In pursuit of a mutually fruitful cooperation between science and practice, one must not only resolutely reject scientism or theoreticism, but also every form of practicism.

In this research project little came of Klafki's proposals to integrate three types of theory (empirical, hermeneutic, and critical), neither with regard to the theory of science, nor to the methodological or method-technical respects. Meanwhile, however, we still think his critical-constructive program aimed at integration was, and still is, a good point of departure for a relevant and nondogmatic science of pedagogy. The shortcomings of the Marburg Elementary School Project, however, have certainly not lessened the burden of proof.

\section{Conclusions}

From a critical-pedagogical perspective we may draw some cautious conclusions. A critical pedagogy that wants to equip its subjects (i.e., children and young people) for communicative competence (Miedema, 1984a, p. 122) must not restrict its view to such macroconcepts as society. Social theory, social analysis, and social criticism must, of course, be integral parts of such a pedagogy. But a critical pedagogy must not get bogged down in these. In the movement toward daily action and daily life the concrete subjects of flesh and blood must be recognizable. Within such a pedagogy, metatheoretical reflection too-and here the argument also concerns the critique-must always play a subordinate part.

In considerations of research, methodology, and the philosophy of science, critical pedagogues will have to identify the frontiers of their conceptual framework, for example, in the possibilities of 
striving for a multimethods integration in pedagogy or in the notion of the aim of pedagogy as communicative competence. Wherever possible, they will have to do so in close cooperation with those immediately involved in practice.

From the Marburg Elementary School Project we learn that the aims must not be too grand. Sometimes real changes are possible, but most of the time minor reforms are all one gets.

On the basis of our analysis of Klafki's critical action research we can make a few recommendations for future research and for a possible fruitful relation between theory and practice in critical pedagogy. Emancipatory processes and research projects must be close to practice, relatively small-scale, and not take too long. Both for theory and practice, a clear understanding and a sound judgment are of the utmost importance. Accurate descriptions and disciplined observation of child raising processes, plus process analysis of initiated strategies for change, are indispensable to achieve these ends. Naturally this must be complemented by clarification, in terms of social theory and object theory, of the influences that might elude the eye of those acting within the context, and which manifest themselves behind people's backs. Such influences silently yet indisputably determine and limit child raising relations and situations. Thus in a critical pedagogy that wants to serve practice (that wants to be a science of action), criticism and hermeneutics belong together. 228 Empirics must find its own place within that relation.

\section{Note}

1. It is not without reason that the German pedagogue, Professor Gstettner (1984), who himself was involved in the initial stage of the project, in his review of the final report speaks critically of a "curriculum factory" (p. 141).

\section{References}

Gstettner, P. (1984). Review of W. Klafki et al., Schulnahe Curriculumentwicklung und Handlungsforschung. Zeitschrift für Pädagogik, 30, 135-141.

Habermas, J. (1970). Towards a theory of communicative competence. Inquiry, $13,360-375$.

Habermas, J. (1971). Knowledge and human interests. London: Heinemann.

Habermas, J. (1984). The theory of communicative action. Vol. I. Reason and the rationalization of society. London: Heinemann.

Klafki, W. (1970). Pedagogy: Theory of a practice. South African Journal of Pedagogy, 4, 23-29.

Klafki, W. (1971). Erziehungswissenschaft als kritisch-konstruktive Theorie: Hermeneutik-Empirie-Ideologiekritik. Zeitschrift für Pädagogik, 17, 351-385. 
Klafki, W. (1975). Decentralised curriculum development in the form of action research (Council of Europe). Information Bulletin, 1, 13-22.

Klafki, W. (1982). Thesen und Argumentationsansätze zum Selbstverständnis kritisch-konstruktiver Erziehungswissenschaft. In E. König \& P. Zedler (Eds.), Erziehungswissenschaftliche Forschung: Positionen, Perspektiven, Probleme (pp. 15-52). München: Schöningh/Fink.

Klafki, W., Scheffer, U., Koch-Priewe, B., Stöcker, H., Huschke, P., \& Stang, H. (1982). Schulnahe Curriculumentwicklung und Handlungsforschung.

Forschungsbericht des Marburger Grundschulprojekts. Weinheim/Basel: Beltz.

Lempert, W. (1969). Bildungsforschung und Emanzipation. Uber ein leitendes Interesse der Erziehungswissenschaft und seine Bedeutung für die empirische Analyse von Bildungsprozessen. Neue Sammlung, 9, 347-363.

Lewin, K. (1958). Action research and minority problems. In K. Lewin (Ed.), Resolving social conflicts (pp. 201-217). New York: Harper \& Row.

Miedema, S. (1984a). Kritische pedagogiek. In F. Beugelsdijk \& S. Miedema (Eds.), Pedagogiek in meervoud. Wegen in het denken over opvoeding en onderwijs (pp. 105-152). Deventer: Van Loghum Slaterus.

Miedema, S. (1984b). De invloed van de kritische pedagogiek in Nederland: een overzicht. Pedagogisch Tijdschrift, 9, 185-194.

Miedema, S. (1985). Idee en werkelijkheid van een kritisch-constructief handelingsonderzoek: een reconstructic. Pedagogisch Tijdschrift, 10, 514-530.

Mollenhauer, K. (1977). Erziehung und Emanzipation. Polemische Skizzen. München: Juventa.

Weniger, E. (1975). Ausgewählte Schriften zur geisteswissen-schafthichen Pädagogik. Weinheim/Basel: Belz. 